\title{
The Chairman's Annual Report for the year 1973-1974
}

This General Meeting marks the completion of the twentieth year of the Society's existence. As our late Chairman, Auberon Herbert said last year, the main body of this Current report would consist of a review of the Society's activities since its foundation in 1954. The recital of the Society's achievements during the past year must therefore of necessity be summary.

During the past session the state of the Society's budget has been satisfactory, thanks to a further generous grant from the Byelorussian Charitable Trust, which accounts for $£ 1,013$ of our total

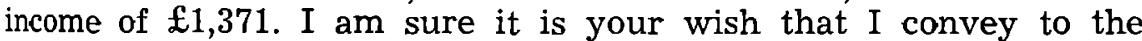
Trustees, and to our friends in the Association of Byelorussians in Great Britain our grateful thanks for their continuing assistance.

The customary Lecture Course, the eighth in the present series, was held once again at the Society of Antiquaries and the following papers were read:-

6 November: 'The origins of contemporary Byelorussian graphic art' (illustrated with slides), Guy Picarda; 4 December: 'The language of the Kucieina Novy Zavet (1652)', Dr. H. Leeming (School of Slavonic and East European Studies); 12 February: 'Byelorussian prayerbooks for laymen in the 16th and 17th centuries', Revd Alexander Nadson (Francis Skaryna Byelorussian Library); 12 March: 'Transformational grammar and Byelorussian linguistics', Dr Roland Sussex (University of Reading); 14 May: 'The poet Aleś Harun (1887-1920)', James Dingley (University of Reading); 11 June: 'The Development of Urbanisation in Byelorussia', Dr Richard A. French (University College, School of Slavonic and East European Studies).

The Council met on 17 July 1974 to deal with the ordinary business activities of the Society. I have the sad duty to inform you that the Chairman Mr Auberon Herbert, who presided at that meeting, died at Pixton Park, Dulverton on 21 July of this year. In accordance with his wishes, Bishop Sipovič and Father Nadson conducted the Requiem and burial service on 26 July. The Hon. Secretary of this Society, the Chairman of the Association of Byelorussians in Great Britain and Mrs Michaluk were also present. Both organisations sent wreaths. He will be greatly missed by us all, and an appreciation of his life and work will be published in the coming issue of the Journal of Byelorussian Studies. The present flourishing state of the Society is due very largely to all his efforts on our behalf in the past. The Society will always remember him with affection.

JOHN JOLLIFFE Chairman 